\title{
HUKUM MATERIIL PENYELESAIAN SENGKETA EKONOMI SYARIAH (TINJAUAN UNDANG- UNDANG DAN HUKUM ISLAM)
}

\author{
Osman \\ (Hukum Keluarga Islam, IAIN Madura, Jln. Raya Panglegur Tlanakan \\ Pamekasan, 69371, osman.ubaidillah@gmail.com) \\ Kudrat Abdillah \\ Fakultas Syariah, IAIN Madura, Jln. Raya Panglegur Tlanakan Pamekasan, \\ 69371,dratlah2024.ka@gmail.com)
}

\begin{abstract}
Abstrak:
Dalam al-Quran dan As-Sunnah peradilan merupakan perkara yang disyariatkan. Allah SWT memerintahkan untuk memutuskan hukum atau menghukumi umat manusia dengan apa yang diturunkan oleh Allah. Nabi Mohammad secara langsung mengadili dan menghukumi perkara yang muncul di tengah-tengah masyarakat dengan hukum-hukum Allah. Nabi Mohammad SAW juga memberikan keputusan dalam beberapa masalah seperti masalah hisbah ketika beliau mendapati pedagang di pasar yang mencampur gandum basah dengan gandum kering; dalam masalah mengenai penetapan harga; dalam perselisihan antara Zubair bin Awwam dan seorang Anshar dalam masalah pengairan dan sebagainya. Saat ini kegiatan ekonomi syariah dan penyelesaiannya juga berkembang pesat di Indonesia seperti penyelesaian sengketa ekonomi syariah ini menjadi kewenangan Pengadilan Agama, selain itu dapat didasarkan pada PERMA Nomor 14 Tahun 2016 tentang Tata Cara Penyelesaian Perkara Ekonomi Syariah. Dalam penelitian ini yang hendak dikaji adalah bagaimana Hukum materiil penyelesaian sengketa ekonomi syariah tinjauan undang-undang dan hukum islam, dengan metode penelitian kepustakaan (library research). (In the Qur'an and As-Sunnah the judiciary is a matter that is prescribed. Allah SWT ordered to break the law or punish humanity with what Allah revealed. Prophet Mohammed directly tried and punished the case that appeared in the midst of society with the laws of God. The Prophet Mohammad SAW also made decisions on a number of issues such as the problem of hisbah when he found traders in the market who mixed wet wheat with dried wheat; in matters regarding pricing; in a dispute between Zubair bin Awwam and an Ansar in the matter of irrigation and so on. At present, sharia economic activities and their solutions are also developing rapidly in Indonesia, such as the resolution of sharia economic disputes is the
\end{abstract}


Osman

Kudrat Abdillah

authority of the Religious Courts, besides that it can be based on PERMA Number 14 of 2016 concerning Procedures for Settling Sharia Economic Cases. In this study, what is intended to be examined is how the material law of sharia economic dispute resolution reviews laws and Islamic law, with library research methods.)

Kata Kunci:

Kata kunci; Hukum Materiil, Ekonomi syariah, Undang-undang, Hukum Islam

\section{Pendahuluan}

Keberadaan ekonomi yang mengalami perkembangan yang pesat, maka sistem penyelesaian sengketapun juga berkontribusi bagi ekonomi Islam dimasa depan. Konsep pemikiran tentang penyelesaian sengketa ekonomi Islam menjadi penting diperdebatkan disebabkan dua hal. Pertama, ekonomi Islam jika menggunakan pendekatan sistem, maka salah satu sub sistem yang juga menjadi instrument penting tegaknya ekonomi Islam dalam menghadapi tantangan ekonomi global adalah menemukan model penyelesaian sengketa ekonomi Islam yang adil bagi para pihak yang bersengketa. Makna adil di sini bukanlah sama rata dan sama rasa, melainkan tidak berbuat zalim antar sesama manusia. Kedua, Manusia sebagai subyek yang terlibat langsung dengan persoalan-persoalan ekonomi bukan tidak mungkin akan berbenturan satu dengan yang lain karena masing-masing mempunyai kualitas, gagasan, sikap dan kepentingan yang berbeda-beda dimana hal tersebut dapat memicu terjadinya konflik di antara mereka. Penyelesaian sengketa dibutuhkan untuk menyelesaikan konflik yang mungkin saja terjadi disebabkan kondisi tersebut. Ekonomi adalah persoalan manusia yang selalu berkembang dengan dinamika. Oleh karena itu selalu diperlukan pemikiran baru untuk pemecahan masalah-masalah ekonomi yang terjadi pada masa kini Keberadaan ekonomi yang mengalami perkembangan yang pesat, maka sistem penyelesaian sengketapun juga 
berkontribusi bagi ekonomi Islam dimasa depan. Konsep pemikiran tentang penyelesaian sengketa ekonomi Islam menjadi penting diperdebatkan disebabkan dua hal. Pertama, ekonomi Islam jika menggunakan pendekatan sistem, maka salah satu sub sistem yang juga menjadi instrument penting tegaknya ekonomi Islam dalam menghadapi tantangan ekonomi global adalah menemukan model penyelesaian sengketa ekonomi Islam yang adil bagi para pihak yang bersengketa. Makna adil di sini bukanlah sama rata dan sama rasa, melainkan tidak berbuat zalim antar sesama manusia. Kedua, Manusia sebagai subyek yang terlibat langsung dengan persoalan-persoalan ekonomi bukan tidak mungkin akan berbenturan satu dengan yang lain karena masing-masing mempunyai kualitas, gagasan, sikap dan kepentingan yang berbeda-beda dimana hal tersebut dapat memicu terjadinya konflik di antara mereka. Penyelesaian sengketa dibutuhkan untuk menyelesaikan konflik yang mungkin saja terjadi disebabkan kondisi tersebut.

Ekonomi adalah persoalan manusia yang selalu berkembang dengan dinamika. Oleh karena itu selalu diperlukan pemikiran baru untuk pemecahan masalah-masalah ekonomi yang terjadi pada masa kini. Di Indonesia sistem ekonomi syariah merupakan sistem ekonomi yang harus diperkuat karena tergolong relatif baru, dibandingkan dengan industri-industri keuangan dan bisnis konvensional. Namun, dalam waktu yang relatif singkat, ekonomi tumbuh dan berkembang sangat pesat. Pada saat ini telah menjadi bagian terpenting dan strategis sebagai salah satu motor penggerak roda perekonomian Indonesia. ${ }^{1}$

Dari penjelasan tersebut dapat dirumuskan "bagaimana Hukum materiil penyelesaian sengketa ekonomi syariah tinjauan undang-undang dan hukum islam".

\footnotetext{
${ }^{1}$ Muhammad Syafi'i Antonio, Bank Syari'ah, Cet. 1 (Jakarta: Gema Insani, 2001), hlm. 4.
} 
Osman

Kudrat Abdillah

Dalam penulisan ini penulis mengalisis dengan critical teori Jurgen Habermas. Dalam teori Jurgen Habermas Ada empat klaim dalam rasionalitas komunikatif atau tindakan komunikatif agar kesaling-pengertian dapat dicapai, yaitu : Pertama, yang dikatakan jelas dan dapat dimengerti (understandability). Kedua, mengungkapkan sesuatu dengan benar (truth). Ketiga, berkata dengan jujur atau mengungkapkan diri apa adanya (sincerity). Keempat, menyatakan sesuatu sesuai dengan norma komunikasi (rightness) sehingga pembicaraan dapat dimengerti orang lain. Disamping empat klaim tersebut, ada empat syarat lagi untuk terlaksananya komunikasi yang ideal/rasional, yaitu : Pertama, setiap partisipan diberi ruang berpartisipasi aktif dalam diskursus dan bebas mengajukan kritik terhadap sudut pandang pastisipan lainnya. Kedua, dialog berjalan bebas tanpa paksaan, dominasi dan permainan kuasa. Ketiga, partisipan dapat memahami perbedaan kriteria validitas klaim teoretis, moral-praktis dan estetis yang muncul dalam dialog dan menyelesaikan dialog serta perbedaaan melalui argumentasi. Keempat, adanya konsensus rasional terbuka terhadap perubahan dan pertimbangan lebih lanjut. ${ }^{2}$

\section{Metode Penelitian}

Penelitian ini menggunakan jenis penelitian kepustakaan (library research), yaitu serangkaian kegiatan yang berkenaan dengan metode pengumpulan data pustaka. ${ }^{3}$ Menurut Abdul Rahman Sholeh, penelitian kepustakaan (library research) ialah penelitian yang mengunakan cara untuk mendapatkan data informasi dengan menempatkan fasilitas yang ada di perpus, seperti buku, majalah, dokumen, catatan kisah kisah sejarah. ${ }^{4}$

\footnotetext{
${ }^{2}$ Ibid.,25-26.

Zaprulkhan, Filsafat Ilmu Sebuah Analisis Kontemporer, (Jakarta: RajaGrafindo Persada, 2015), 291.

3 Mahmud,metode penelitian pendidik an,(Bandung: pustaka setia, 2011), hlm.31

${ }^{4}$ Abdul Rahman Sholeh, Pendidik an Agama dan Pengembangan untuk Bangsa, ( Jakarta: PT. Raja Grafindo Persada, 2005), hlm. 63
} 
Atau penelitian kepustakaan murni yang terkait dengan obyek penelitian.

\section{Hukum Materiil Penyelesaian Sengketa Ekonomi Syariah Pada Masa Nabi Dan Sahabat}

Ajaran sistem penyelesaian sengketa Islam sebenarnya dapat kita lihat dari kejadian sehari-hari yang terjadi di masyarakat Arab dalam sejarah Islam pada masa Rasulullah saw. Ajaran ini diambil dari kasus-kasus yang terjadi dan ditauladani sampai hari ini. Paling tidak ada dua model penyelesaian sengketa Islam yang dapat dijadikan acuan, yaitu; Pertama, penyelesaian sengketa dengan al-Qadhâ' (Peradilan). Kedua, penyelesaian sengketa melalui tahkim (perwasitan/arbitrase). Al-Qadhâ' berasal dari kata qadhâyaqdhî-qadhâ'[an]; jamaknya aqdhiyyah. Kata al-qadhâ' merupakan kata musytarak, memiliki banyak makna. Al-Quran mencantumkan kata al-qadhâ' dalam banyak ayat yang semuanya mengunakan makna bahasa, di antaranya: menetapkan (QS 2: 117); menentukan (QS 6: 2); memerintahkan sesuatu sebagai kepastian (QS 17: 23); memerintahkan dan memutuskan sesuatu (QS 33: 36); menyelesaikan (QS 14: 22; 28 : 29); mengakhiri (QS 33: 37); membuat (QS 41: 12); menetapkan sesuatu yang wajib terlaksana atau mewajibkan sesuatu (QS 8: 42); binasa atau mati (QS 33: 23); menyelesaikan dan membinasakan (QS 6: 58); dan sebagainya. Sekalipun secara bahasa kata al-qadhâ' memiliki banyak makna, secara tradisi ia akhirnya lebih difokuskan pada makna yang berkaitan dengan praktik dan putusan peradilan. Syariatpun memutlakkan istilah al-qadhâ' dalam masalah praktik dan Putusan Peradilan. ${ }^{5}$

Para ulama memberikan beberapa definisi al-qadhâ dalam pengertian syar'i ini. Menurut Al-Khathib asy-Syarbini, al-qadhâ' adalah penyelesaian perselisihan di antara 2 (dua)

\footnotetext{
5 Al-Qadla', Yahya Abdurrahman, dalam http://hizbut-tahrir.or.id/main.php? page $=$ alwaie $\& i d=67 \&$ print $=1$, diakses tanggal 15 Juni 2007.
} 
Osman

Kudrat Abdillah

orang atau lebih dengan hukum Allah SWT. ${ }^{6}$ Dalam Fath alQadîr al-qadhâ' diartikan sebagai al-ilzâm (pengharusan); dalam Bahr al-Muhîth diartikan sebagai penyelesaian perselisihan dan pemutusan persengketaan; sedangkan dalam Badâ'i' ash-Shanâ'i' diartikan sebagai penetapan hukum di antara manusia dengan haq (benar). ${ }^{7}$

Al-Qadhâ' (Peradilan) merupakan perkara yang disyariatkan di dalam al-Quran dan as-Sunnah. Allah Swt memerintahkan untuk memutuskan hukum atau menghukumi manusia dengan apa yang diturunkan oleh Allah. ${ }^{8}$ Rasul SAW secara langsung mengadili dan menghukumi perkara yang muncul di tengah-tengah masyarakat dengan hukum-hukum Allah. Rasul juga memberikan keputusan dalam beberapa masalah pernikahan, masalah harta, muamalah, dan 'uqûbât umumnya; juga dalam masalah hisbah seperti ketika beliau mendapati pedagang di pasar yang mencampur gandum basah dengan gandum kering; dalam masalah mazhâlim mengenai penetapan harga; dalam perselisihan antara Zubair bin Awwam dan seorang Anshar dalam masalah pengairan dan sebagainya. Kasus ini adalah persengketaan hak pengairan atau irigasi antara Zubair bin Awwâm dan seorang Ansar. Seorang sahabat dari kalangan Ansar menggugat Zubair kepada Rasulullah SAW. karena Zubair dianggap telah menahan dan merugikan haknya atas air dan pengairan, padahal hak tersebut merupakan hak umum yang mesti dijamin untuk setiap orang. Peristiwa ini termaktub dalam hadis berikut yang Artinya;

"Hadis yang berasal dari Yûsuf, dari al-Laits, dari Ibn Shihâb, dari 'Urwah, dari 'Abdillâh Ibn Zubair r.a. bahwa sesungguhnya seorang dari golongan Ansar berperkara dengan Zubair di hadapan Rasulullah SAW. mengenai aliran air (irigasi) diHarrah. Orang Ansar tersebut

\footnotetext{
${ }^{6}$ Muhammad Khathib asy-Syarbini, Mughn al-Muhtaj, iv/371-372, Dar al-Fikr, Beirut; Defenisi ini juga dipilih oleh asy-Syarwani, Hawasyi asy-Syarwani, $\mathrm{X} / 101$, Dar al-Fikr, Beirut. Tt

7 Al-Qadla', Yahya Abdurrahman, dalam http://hizbut-tahrir.or.id/main.php? page=alwaie\&id=67\&print=1, diakses tanggal 15 Juni 2007. ${ }^{8}$ ibid
} 
berkata: "Alirkanlah air itu!" Zubair menolak. Mereka lalu bersengketa di hadapan Rasulullah SAW. Rasulullah SAW. bersabda: "Pakailah air itu hai Zubair, lalu alirkan ke tetanggamu!" Orang Ansar tersebut marah dan berkata: "Mentang-mentang Zubair anak bibimu." Rona muka Rasulullah SAW. berubah mendengar ucapan tersebut. Lalu beliau bersabda kepada Zubair sekali lagi: "Pakailah air itu hai Zubair, lalu alirkan ke tetanggamu!" Zubair berkata: "Saya menduga ayat ini (Maka demi Tuhanmu, mereka belumlah beriman sehingga mereka menjadikan kamu hakim terhadap perkara yang mereka perselisihkan) turun berkenaan dengan peristiwa tersebut"(H.R. Bukhârî). ${ }^{9}$

Ketika kekuasaan Negara Islam semakin luas, Rasulullah Saw mengangkat beberapa sahabat sebagai qadhi (hakim) yang beliau tempatkan di beberapa daerah, seperti Muadz bin Jabal di daerah Janad dan Ali bin Abi Thalib di daerah Yaman. Qadhi pada masa Rasul saw. antara lain: Umar bin al-Khathab, Ali bin Abi Thalib, Ibn Mas'ud, Ubay bin Kaab, Zaid bin Tsabit, Abu Musa al-Asy'ari, ${ }^{10}$ dan Muadz bin Jabal.

Praktik al-Qadhâ' (Peradilan) oleh Rasul Saw bukan hanya dalam masalah perselisihan (al-Khushûmât), tetapi juga dalam masalah hisbah dan mazhâlim. Abu Abdillah berkata, "Perkataan sebagian bahwa al-Qadhâ' adalah penyelesaian antara dua orang yang bersengketa atau lebih jelas masih kurang."11 Sebab, definisi tersebut belum bersifat jâmi', yakni mencakup seluruh realita alQadhâ'. Al-Qadhi an-Nabhani menjelaskan, lembaga al-Qadhâ inilah yang menyelesaikan perselisihan atau sengketa yang terjadi di antara anggota masyarakat; atau mencegah sesuatu yang bisa membahayakan hak-hak jamaah/umum; atau menyelesaikan persengketaan

\footnotetext{
${ }^{9}$ Muhammad bin Ismâ'îl Abû 'Abdillâh al-Bukhârî,Shahîh al- Bukhârî, Cet. 3, juz II (Beirût: Dâr Ibn Katsîr, 1987), h. 832

10 Enam orang ini sesuai penuturan Masyruq yang diriwayatkan oleh Thabrani, lihat Abd al-Hayyi al- Kattani, at-Tarâtîb al-Idâriyah, I/258, Dar al-Kitab al'Arabi, Beirut., hlm. 258.

11 Al-Qadla', Yahya Abdurrahman, dalam http://hizbut-tahrir.or.id/main.php? page $=$ alwaie $\& \mathrm{id}=67 \&$ print $=1$, diakses tanggal 15 Juni 2007
} 
Osman

Kudrat Abdillah

antara masyarakat dengan aparatur negara. Hal ini menjelaskan tiga kelompok perkara dan macam lembaga alQadhâ': pertama Perselisihan di antara manusia dalam perkara muamalah dan 'uqûbât. Perkara ini ditangani oleh al-qâdhî (jamaknya alqudhât), kadang disebut Qudhât al-Khushûmât. kedua Perkara yang dapat membahayakan hak jamaah/umum; disebut Hisbah. Perkara ini ditangani oleh Qâdhî al-Hisbah atau al-Muhtasib. ketiga Sengketa masyarakat dengan negara dan aparaturnya, atau kezaliman yang dilakukan oleh atau akibat dari kebijakan negara dan aparaturnya. Inilah yang disebut mazhâlim dan ditangani oleh Qâdhî al-Mazhâlim. Khalifah bisa mengangkat seorang qadhi dengan wilayah kerja mencakup seluruh wilayah Khilafah sekaligus membawahi seluruh qadhi yang ada. Pejabat ini disebut Qâdhî al-Qudhât. Qadhi Abu Yusuf adalah orang pertama yang mendapat sebutan ini. ${ }^{12}$

Jabatan qadhi (al-qudhât) sudah ada sejak masa Rasul SAW. dan terus ada sepanjang sejarah Islam. Adapun untuk perkara hisbah, Rasul SAW. menangani sendiri perkara ini seperti saat menginspeksi pasar dan menemukan gandum basah yang dicampur dengan yang kering, lalu beliau memerintahkan agar yang basah ditaruh di atas, di samping yang kering. Pada masa Umar bin al-Khaththab, ia juga langsung menanganinya, seperti saat menginspeksi pasar, Umar menemukan susu yang dicampur air lalu ia tumpahkan untuk mendidik para pedagang, atau ketika ia memukul dan memisahkan laki-laki dan wanita yang berdesakdesakan di tempat pengambilan air. Saat yang sama Umar juga mengangkat pejabat khusus untuk mewakilinya menjalankan tugas hisbah, dan disebut wilâyah as-sûq. Baru pada masa alMahdi diangkat qadhi khusus untuk menangani hisbah dan disebut alMuhtasib, dan sejak saat itu terus terpelihara sebagai

12 Lihat, Abdurrahman al-Baghdadi, Ulama dan Penguasa Dimasa Kejayaan dan Kemunduran, (Jakarta: GIP, 1994), hlm. 31. 
bagian alQadhâ'. Keberadaan al-Muhtasib ini bersandar pada as-Sunnah berupa perbuatan Rasul SAW. tersebut. ${ }^{13}$

Dalam masalah mazhâlim, Rasul SAW juga menanganinya secara langsung; seperti dalam masalah penolakan beliau untuk melakukan penetapan harga, atau dalam masalah pengairan antara Zubair dan seorang laki-laki dari Anshar. Begitu juga Khulafaur Rasyidin; menangani langsung perkara mazhâlim sekaligus belum menyediakan waktu khusus. Baru Khalifah Abdul Malik bin Marwan yang menyediakan waktu khusus untuk meneliti masalah mazhâlim, tanpa langsung memutuskan. Jika ada masalah atau perlu keputusan hukum, ia mengajukannya kepada qadhi-nya, yaitu Abi Idris al-Azadi. Karena itu, ia adalah qadhi mazhâlim saat itu. Baru pada masa Abassiyah diangkat qadhi khusus untuk menangani perkara mazhâlim ini. Jabatan ini terus ada dan menjadi bagian dari al-Qadhâ'. Pengangkatan qadhi mazhâlim ini juga didasarkan pada as-Sunnah berupa perbuatan Rasul Saw.

Penyelesaian sengketa Islam lainnya, dikenal dengan tahkim atau perwasiatan. Model ini juga sudah lama dipraktekan sejak masa Rasulullah Saw. Lebih lanjut dikatakan pula bahwa tahkim adalah berlindungnya dua pihak yang bersengketa kepada orang yang mereka sepakati dan setujui serta rela menerima keputusannya untuk menyelesaikan persengketaan mereka, atau didefinisikan juga sebagai tempat berlindung bagi dua pihak yang bersengketa kepada orang yang mereka tunjuk (sebagai penengah) untuk memutuskan/menyelesaikan perselisihan yang terjadi di antara mereka. ${ }^{14}$

Jika dilihat dari sejarah, tahkim telah dikenal dan merupakan peninggalan tradisi Arab pra Islam yang kemudian

\footnotetext{
13 Imam al-Mawardi, Al-Ahkâm as-Sulthâniyyah wa al-wilâyah ad-Dîniyyah (Hukum Tata Negara dan Kepemimpinan dalam Takaran Islam), penerjemah, Abdul Hayyi al-Kattani dan Kamaluddin Nurdin, (Jakarta: GIP, 2000), hlm. 160.

14 Ensiklopedi Hukum Islam, Jilid V, (Jakarta: PT.Ichtiar Baru Van Hoeve, 1997), hlm. 157.
} 
Osman

Kudrat Abdillah

diislamkan oleh Nabi Muhammad SAW. Dalam masyarakat pra Islam, tidak ada kekuasaan politik dan sistem peradilan terorganisir. Namun demikian, jika terjadi persengketaan mengenai hak milik, hak waris dan pelanggaran hukum selain pembunuhan, maka persengketaan tersebut diselesaikan melalui bantuan juru damai atau wasit yang ditunjuk oleh masing-masing pihak yang bersengketa. Untuk tugas itu tidak ada pejabat resmi, melainkan lebih bersifat ad hoc. Artinya, jika terjadi persengketaan maka ditunjuk juru damai yang bertugas untuk menyelesaikan kasus tersebut. Juru damai tersebut sering disebut hakam. ${ }^{15}$

Pada masa pra Islam, hakam atau juru damai itu harus memenuhi beberapa kualifikasi. Di antara syarat yang terpenting bagi mereka adalah harus cakap dan memiliki kekuatan supranatural atau adikodrati. Oleh karena itu, dalam pemeriksaan dan penyelesaian persengketaan di kalangan mereka, hakam lebih banyak menggunakan kekuatan firasat daripada menghadirkan alat-alat bukti seperti saksi-saksi atau pengakuan. ${ }^{16}$ Namun setelah Islam datang dan berkembang yang dibawakan oleh Nabi Muhammad Saw, lembaga perwasitan terus berjalan dan dikembangkan sebagai alternatif penyelesaian sengketa dengan memodifikasi yang pernah berlaku pada masa pra-Islam. Hal-hal yang bersifat takhayul dan syirik mulai dieliminir secara bertahap dan disesuaikan dengan al-Qur'an dan as-Sunnah. ${ }^{17}$

Adapun dasar hukum bertahkim adalah sebagaimana yang terdapat di dalam al-Qur'an surat al-Maidah ayat 95 yang artinya :

"Hai orang-orang yang beriman, janganlah kamu membunuh binatang buruan, ketika kamu sedang ihram. Barangsiapa di antara kamu membunuhnya dengan sengaja, maka dendanya ialah mengganti

\footnotetext{
${ }^{15}$ Fathurrahman Djamin, Op.Cit., hlm. 30.

${ }^{16}$ Ibid

17 A. Rahmat Rosyadi dan Ngatino, Arbitrase dalam Perspektif Islam dan Hukum Positif, (Bandung : PT. Citra Aditya Bhakti, 2002), hlm. 50.
} 
dengan binatang ternak seimbang dengan buruan yang dibunuhnya, menurut putusan dua orang yang adil di antara kamu sebagai had-yad yang dibawa sampai ke Ka'bah atau membayar kaffarat dengan memberi makan orang-orang miskin atau berpuasa seimbang dengan makanan yang dikeluarkan itu, supaya dia merasakan akibat buruk dari perbuatannya. Allah telah memaafkan apa yang telah lalu. Dan barangsiapa yang kembali mengerjakannya, niscaya Allah akan menyiksanya. Allah Maha Kuasa lagi mempunyai menyiksa. ${ }^{18}$ dikatakan:

Selanjutnya, di dalam Surat an-Nisa' ayat 35 juga "Dan jika kamu khawatir ada persengketaan antara keduanya, maka kirimkan seorang hakam dari keluarga laki-laki dan seorang hakam dari keluarga perempuan. Jika kedua orang hakam itu bermaksud mengadakan perdamaian, niscaya Allah memberi taufik kepada suami isteri. Sungguh Allah itu Maha Mengetahui lagi Maha Mengenal".

Perintah mengambil hakam dalam ayat di atas, adalah mengenai persengketaan yang terjadi antara suami isteri. Namun oleh karena tujuan hakam itu adalah untuk mendamaikan dan ini merupakan usaha yang terpuji di sepanjang waktu, maka segala persengketaan dapat diqiyaskan dengan persengketaan rumah tangga ini. Dalam Hadis yang diriwayatkan dari Syuraih bin Hani dari ayahnya, ia dijuluki Aba al-Hakam (Bapak juru damai) oleh kaumnya. Nabi Muhammad SAW bersabda :

"Sesungguhnya Allah SWT lah yang telah menjadi Hakam, kepadaNya lah hukum dikembalikan. Mengapa kamu dipanggil Abu al-Hakam? "Abu Syureih menjawab: bahwa sesungguhnya kaumku bila bertengkar akan datang kepadaku minta penyelesaian, dan kedua belah pihak akan rela dengan putusanku". Mendengar jawaban Abu Syureih itu Rasulullah saw lalu berkomentar: "Alangkah baiknya perbuatanmu itu! Apakah kamu punya anak?Abu Syureih menjawab: ya saya punya anak, yaitu: Syureih, Abdu, dan Musallam. Siapa yang paling tua?, tanya Rasulullah. Jawab Abu Syureih: "Siapa yang paling tua?, tanya Rasulullah. Jawab Abu Syureih: yang paling tua

\footnotetext{
${ }^{18}$ Departemen Agama RI, al-Qur'an dan Terjemahannya
} 
Osman

Kudrat Abdillah

adalah Syureih. Kata Rasulullah: kalau begitu engkau adalah Abu Syureih". ${ }^{19}$

Di samping Al-Qur'an dan As-Sunnah di atas, dalil hukum ketiga yaitu ijma' menunjukkan juga adanya kesepakatan antara para ulama atas keabsahan praktik tahkim. Pada masa sahabat telah terjadi penyelesaian sengketa secara arbitrase, dan tak ada seorangpun yang menentangnya. Contoh ijma' yang melandasi tahkim adalah peristiwa yang terjadi antara Umar bin Khattab dan seorang penjual kuda. Ketika itu Umar ingin membeli kuda yang ditawarkan dan Umar mencoba kuda tersebut. Pada waktu ditunggangi kaki kuda tersebut patah. Lalu Umar bermaksud untuk mengembalikan kuda tersebut kepada pemiliknya, tetapi pemiliknya menolak. Kemudian Umar berkata: “Tunjuklah seseorang untuk menjadi hakam yang akan bertindak sebagai penengah di antara kita berdua." Pemilik kuda berkata: "Aku setuju Syureih al-Iraqy untuk menjadi hakam. ${ }^{20}$

Kemudian mereka berdua bertahkim kepada Syureih dan Syureih menyatakan kepada umar: "Ambilah apa yang telah kamu beli atau kembalikan seperti keadaan semula (tanpa cacat)." Maksudnya, Umar harus membayar harga kuda tersebut. Cara penyelesaian perselisihan semacam ini tidak ada yang membantahnya. Selanjutnya menurut Ibnu Qayyim alJauziah seorang ulama terkemuka dalam Mazhab Hanbali bahwa salah satu asar Umar bin al-Khattab menyebutkan pula "Selesaikanlah pertikaian sehingga mereka berdamai, sesungguhnya penyelesaian melalui pengadilan akan menyebabkan timbulnya rasa benci di antara mereka". ${ }^{21}$

Berdasarkan ketentuan al-Qur'an dan as-Sunnah yang melandasi keberadaan hakam di atas, maka keberadaan lembaga hakam untuk menyelesaikan sengketa dibenarkan dalam Islam. Hakam ditunjuk untuk menyelesaikan sengketa

\footnotetext{
${ }^{19}$ Ensiklopedi Hukum Islam, Jilid V, hlm. 158.

${ }^{20}$ Ibid. hlm. 159.

${ }^{21}$ Ibid
} 
bukan oleh pihak pemerintah, tetapi ditunjuk langsung oleh dua orang yang bersengketa. Oleh sebab itu, hakam atau lembaga hakam bukanlah resmi pemerintah, tetapi swasta. Aktifitas penunjukkan itu disebut tahkim, dan orang yang ditunjuk disebut hakam (jamaknya hukkam). Penyelesaian sengketa yang dilakukan oleh hakam dikenal di abad modern dengan arbitrase. ${ }^{22}$

Fungsi hakam sangat berkaitan erat dengan kewenangan hakam itu sendiri. Adapun kewenangan hakam adalah menyelesaikan sengketa-sengketa yang diajukan para pihak kepadanya. Sengketa-sengketa tersebut adalah sengketa yang berkaitan dengan hak perorangan, di mana ia (perorangan) berkuasa penuh apakah ia akan menuntut atau tidak, atau ia memaafkan atau tidak. Satu hal yang menjadi tujuan utama praktek arbitrase adalah menyelesaikan sengketa dengan jalan damai. Sejalan dengan prinsip itu, sengketa yang akan diselesaikan oleh hakam adalah sengketa-sengketa yang menurut sifatnya menerima untuk didamaikan. Sengketasengketa yang bisa didamaikan seperti sengketa-sengketa yang menyangkut dengan harta benda dan yang sama sifatnya dengan itu, umpamanya sengketa dalam pergaulan rumah tangga dan sebagainya, yang berupa hak perorangan. Sedangkan sengketa-sengketa yang berkaitan dengan hak umum atau hak-hak Allah tidak termasuk ke dalam kewenangan hakam. Aturan-aturan di bidang ini bila dilanggar, sepenuhnya menjadi kewenangan penguasa (hakim) untuk menyelesaikannya. ${ }^{23}$

Lembaga arbitrase atau disebut dengan tahkim ini dalam menangani suatu persoalan ternyata di kalangan ulama fiqh terjadi perbedaan pendapat. Menurut ulama mazhab Hanafi, lembaga tahkim tidak boleh menyelesaikan perselisihan yang menyangkut masalah hudud atau qisas, sebab penyelesaian melalui tahkim adalah penyelesaian dengan perdamaian,

\footnotetext{
${ }^{22}$ Satria Efendi M.Zein, Arbitrase Dalam Syariat Islam, hlm. 8.

${ }^{23}$ Ibid., hlm. 16 .
} 
Osman

Kudrat Abdillah

sedangkan qisas dan hudud tidak boleh diselesaikan dengan jalan perdamaian. Keputusan hakam juga bersifat tidak pasti (mengandung keraguan/syubhat), sedangkan masalah hudud dan qisas tidak boleh diputuskan sepanjang masih terdapat syubhat. Rasulullah Saw bersabda: ${ }^{24}$

"Tinggalkan hukuman hudud jika terdapat keraguan" (HR.AlBaihaqi, at-tarmidzi dan al-Hakim).

Menurut al-Marginani, penyebutan secara khusus hudud dan qisas sebagai persoalan yang tidak boleh diselesaikan melalui tahkim menunjukkan bahwa semua persoalan selain kedua masalah tersebut boleh diselesaikan melalui tahkim. Selanjutnya, dikatakan pula bahwa juru damai tidak boleh menyelesaikan perselisihan yang terjadi antara kaum kerabatnya, seperti kedua orang tuanya, istri, dan anaknya. Apabila hal itu dilakukannya maka keputusannya batal. Sedang menurut Mazhab Syafi'i, hanya masalah hudud dan ta'zir yang tidak boleh diselesaikan melalui tahkim, sebab kedua hal tersebut murni hak Allah Swt. Menurut jumhur Ulama Mazhab Hanafi, persoalan yang tidak boleh diselesaikan melalui tahkim ialah nikah, li'an, qazf, dan qisas sebab terhadap masalah-masalah tersebut terdapat wewenang pemerintah (al-Imam), yang penyelesaiannya dilakukan oleh hakim pengadilan. Sedangkan ahli fiqh Mazhab Maliki berpendapat, bahwa wilayah tahkim diperoleh dari orang perorangan dan tahkim tersebut merupakan bagian dari lembaga qada' yang berkaitan dengan persoalan harta, tidak berwenang menyelesaikan perkaraperkara hudud dan qisas. ${ }^{25}$

Berdasarkan pendapat para jumhur ulama fiqh di atas, maka dapat disimpulkan bahwa sebagian besar ulama berpandangan wilayah tahkim atau badan arbitrase di dalam Islam adalah untuk menyelesaikan masalah keperdataan. Penyelesaian sengketa yang dilakukan melalui lembaga

24 Fathur Rahman, Hadits-Hadits tentang Peradilan Agama (Jakarta: Bulan Bintang, 1977), hlm. 242.

${ }^{25}$ Ensiklopedi Hukum Islam, Jilid V, hlm. 1752 
arbitrase ini dilakukan oleh para arbiter. Mereka akan mewakili kepentingan para pihak yang bersengketa untuk mengajukan suatu solusi atas sengketa yang terjadi dan solusi itu dapat diterima oleh kedua belah pihak, sehingga akhirnya dapat menyelesaikan perselisihan secara damai dan tidak membawanya ke pengadilan. Adapun mengenai kekuatan hukum bagi putusan tahkim, ulama masih berbeda pendapat. Menurut ulama Mazhab Hanafi, apabila hakam telah memutuskan perkara pihak-pihak yang bertahkim dan mereka menyetujuinya, maka pihak-pihak yang bertahkim terikat dengan putusan tersebut. Apabila mengadukannya ke pengadilan dan hakim sependapat dengan putusan hakam, maka hakim pengadilan tidak boleh membatalkan putusan hakam tersebut. Akan tetapi, jika hakim pengadilan tidak sependapat dengan putusan hakam, maka hakim berhak membatalkannya. Sedangkan menurut pendapat ulama Mazhab Maliki dan Hanbali, apabila keputusan yang dihasilkan oleh hakam melalui proses tahkim tidak bertentangan dengan kandungan al-Qur'an, asSunnah dan ijma' maka hakim pengadilan tidak berhak membatalkan putusan hakam, sekalipun hakim pengadilan tersebut tidak sependapat dengan putusan hakam. ${ }^{26}$

Sedang mengenai pembatalan putusan tahkim, menurut pendapat jumhur ulama fiqh kebolehan pembatalannya oleh kedua belah pihak yang bersengketa ditentukan oleh waktu dan/atau tahapan proses yang dilalui. Untuk itu terdapat beberapa kemungkinan: Pertama, apabila pembatalan tersebut dilakukan sebelum masuk proses tahkim, maka ulama fiqh sependapat menyatakan bahwa hal itu dibenarkan, sebab tahkim tergantung kepada kerelaan dan persetujuan kedua belah pihak yang bersengketa, sehingga tahkim tidak boleh

\footnotetext{
${ }^{26}$ 4Ibnu Qudamah seorang ulama Mazhab Hanbali berpendapat, bahwa apabila hakam menulis putusannya kepada seorang hakim di antara hakim-hakim muslim di pengadilan maka hakim di pengadilan tersebut harus menerima dan melaksanakan putusan hakam dimaksud. Ensiklopedi Hukum Islam, hlm. 158.
} 
Osman

Kudrat Abdillah

dilakukan tanpa kerelaan dan persetujuan masing-masing pihak. Kedua, apabila pembatalan tahkim dilakukan setelah memasuki prosesnya, maka ada dua pendapat; yaitu boleh dan dapat dibenarkan sebab pada waktu itu proses dan keputusan belum sempurna, sehingga sama saja dengan pembatalan ketika belum memasuki prosesnya. Selanjutnya,hal tersebut tidak boleh/tidak dibenarkan dengan alasan apabila dibolehkan, maka masing-masing pihak akan membatalkan pelaksanaan tahkim, yang pada mulanya disetujui. Dengan demikian maksud dan tujuan pengadaan lembaga tahkim tidak akan dapat dicapai. Ketiga, apabila pembatalan dilakukan setelah putusan dikeluarkan maka pembatalan tidak dapat dibenarkan. Karena putusan hukum telah keluar dari wewenang yang sempurna dan sah. Dikatakan telah sempurna dan sah karena putusan tersebut dihasilkan berdasarkan perdamaian (assulh) dan tidak dibenarkan seseorang membatalkan sebuah perdamaian yang telah ditetapkan. ${ }^{27}$

\section{Hukum Materiil Penyelesaian Sengketa Ekonomi Syariah Dalam Undang-Undang Peradilan Agama}

Penyelesaian sengketa melaui jalur non litigasi diatur dalam satu pasal, yakni Pasal 6 UU No. 30 Tahun 1999 tentang Arbitrase dan Alternatif Penyelesaian Sengketa yang menjelaskan tentang mekanisme penyelesaian sengketa. Arbitrase merupakan cara penyelesaian sengketa perdata di luar pengadilan umum yang didasarkan perjanjian arbitrase secara tertulis oleh pihak yang bersengketa. Perjanjian arbitrase merupakan kesepakatan berupa klausula arbitrase yang tercantum dalam suatu perjanjian tertulis yang dibuat para pihak sebelum atau setelah timbul sengeketa. Dalam konteks hukum Islam, penyelesaian sengketa melalui arbitrase

\footnotetext{
${ }^{27}$ Selanjutnya dikatakan menurut sebagian ulama Mazhab Syafi'i, pembatalan tahkim dapat dan boleh dilakukan pada waktu dan tahapan manapun, sebab dasar dari tahkim adalah kerelaan masing-masing pihak yang berselisih, sehingga tanpa kerelaan tersebut tidak dapat dilakukan dan jika tetap dilakukan juga maka akan menghasilkan putusan yang sia-sia (tidak mengikat). Satria Efendi M.Zein, Arbitrase Dalam Syariat Islam, hlm. 8-9
} 
ini dapat disepadankan dengan istilah tahkim. Kata tahkim ini berasal dari kata kerja hakama yang secara harfiah berarti menjadikan seseorang sebagai penengah bagi suatu sengketa. ${ }^{28}$

UU No.14 Tahun 1970 (Pokok-Pokok Kekuasaan Kehakiman) dan juga UU Mahkamah Agung No.14 Tahun 1985 pada waktu itu memang memberi peluang adanya badan arbitrase di kalangan masyarakat. Berdasarkan hal di atas, maka Badan Arbitrase Muamalat Indonesia (BAMUI) berdiri di Indonesia pada tanggal 21 Oktober 1993 oleh Majelis Ulama Indonesia dengan berlandaskan musyawarah dan mufakat. Penyelesaian sengketa lewat Badan Arbitrase Islam dilakukan dengan jalan musyawarah, atau perdamaian (islah). Adanya musyawarah berarti setiap pihak mau berkompromitanpa meninggalkan dendam dan ganjalan. Esensinya tidak memutus tali silaturrahmi di antara para pihak yang bersengketa.

Di Indonesia, sejak berdirinya BAMUI tahun 1993 hingga berganti nama BASYARNAS tahun 2004, setidaknya ada 12 (dua belas) kasus/sengketa ekonomi Islam khususnya perbankan syari'ah yang sudah diselesaikan oleh BASYARNAS. Perkembangan sekarang ini, penyelesaian sengketa ekonomi Islam yang dulunya diselesaikan melalui Badan Arbitrase Syariah sudah dapat diselesaikan melalui lembaga peradilan yang ada. Yaitu Peradilan Agama di Indonesia. Hal ini berkaitan erat dengan diperluasnya kompetensi Peradilan Agama melalui Revisi Undang-Undang Peradilan Agama No.7 Tahun 1989 menjadi Undang-Undang No.3 Tahun 2006. Melalui Pasal 49 UU No.3 Tahun 2006 ini diatur kewenangan Peradilan Agama selain menyelesaikan sengketa-sengketa hukum keluarga, seperti perkawinan, perceraian, pengasuhan anak, waris, wasiat, hibah diperluas kewenangannya untuk menyelesaikan sengketa ekonomi Islam.

Atas perubahan kewenangan peradilan agama yang sekarang semakin diperluas lagi, hal ini dapat dilihat sebagai

\footnotetext{
${ }^{28}$ Suhrawardi K Lubis. Hukum Ekonomi Islam (Jakarta: Sinar Grafika, 2000), hlm. 184
} 
Osman

Kudrat Abdillah

wujud penerapan dari asas personalitas keIslaman yang menyatakan bahwa terhadap orang Islam berlaku hukum Islam, apabila terjadi pelanggaran dan/atau sengketa diselesaikan menurut hukum Islam oleh Hakim Peradilan Agama. Asas personalitas keIslaman melakat pada perkara sebagai dasar penentuan kekuasaan Peradilan Agama, bukan melekat pada pihak-pihak yang bersengketa. ${ }^{29}$

\section{Hukum Materiil Penyelesaian Sengketa Ekonomi Syariah Menurut PERMA}

Berkaitan dengan tata cara penyelesaian sengketa ekonomi syariah di Pengadilan Agama, pada tahun 2016, Mahkamah Agung telah mengeluarkan Peraturan Mahkamah Agung (PERMA) Nomor 14 Tahun 2016 tentang Tata Cara Penyelesaian Perkara Ekonomi Syariah. PERMA ini untuk menjamin pelaksanaan penyelesaian sengketa ekonomi syariah yang lebih sederhana, cepat dan biaya ringan. Berdasarkan PERMA Nomor 14 Tahun 2016 maka perkara ekonomi syariah dapat diajukan dalam bentuk gugatan sederhana atau dengan acara biasa. Pemeriksaan perkara dengan acara sederhana adalah pemeriksaan terhadap perkara ekonomi syariah yang nilainya paling banyak Rp. 200.000.000,00 (dua ratus juta rupiah). Pemeriksaan ini mengacu pada Peraturan Mahkamah Agung Nomor 2 Tahun 2015 tentang Tata Cara Penyelesaian Gugatan Sederhana kecuali hal-hal yang diatur secara khusus.

Penanganan perkara ekonomi syariah dengan cara sederhana mengacu kepada PERMA Nomor 2 Tahun 2015 tentang Tata Cara Penyelesaian Gugatan Sederhana atau biasa dikenal dengan istilah small claims court. Sementara itu, penanganan perkara ekonomi syariah dengan cara biasa tetap mengacu kepada pelbagai peraturan perundang-undangan

\footnotetext{
${ }^{29}$ A. Mukti Arto, Garis Batas Kekuasaan Peradilan Agama dan Pengadilan Negeri, Penerapan Asas Personalitas KeIslaman sebagai Dasar Penentuan Kekuasaan Peradilan Agama, dalam Varia Peradilan No.253 Desember 2006, hlm. 20 .
} 
yang berlaku. Baik dalam hal gugatan sederhana maupun gugatan biasa, penggugat dapat mengajukan perkaranya dengan datang kepaniteraan atau melalui pendaftaran elektronik. Bedanya, jika hendak mendaftarkan gugatan sederhana, penggugat cukup mengisi formulir atau blanko gugatan yang disediakan pengadilan. Isinya menguraikan identitas penggugat dan tergugat; penjelasan ringkas duduk perkara (posita); dan tuntutan penggugat (petitum). Selain itu, ketika mendaftarkan perkaranya, penggugat wajib melampirkan bukti surat yang sudah dilegalisasi. Pendaftaran perkara secara elektronik sesungguhnya bukan hal baru lagi di peradilan agama. Sejumlah pengadilan sudah menerapkannya, dengan beberapa varian. Namun, sejauh ini belum ada satupun regulasi yang mengaturnya. ${ }^{30}$

\section{Penutup}

Penyelesaian sengketa ekonomi syariah pada masa Nabi Muhammad SAW dan masa sahabat dapat dilakukan dengan dua cara yaitu; Pertama, penyelesaian sengketa dengan alQadhâ' (Peradilan). Kedua, penyelesaian sengketa melalui tahkim (perwasitan/arbitrase), dasar dari kedua cara penyelesaian tersebut adalah Al-Qua'an, As-Sunnah, dan Ijma' Ulama'. Penyelesaian sengketa ekonomi syariah di Indonesia dapat dilakukan dengan dua cara yaitu pertama dengan cara di luar pengadilan (non litigasi)/ arbitrase yang didasarkan pada Pasal 6 UU No. 30 Tahun 1999, kedua di dalam pengadilan (litigasi) yang didasarkan pada pasal 49 UndangUndang No.3 Tahun 2006, dan PERMA Nomor 2 Tahun 2015.

Berdasarkan critical teori jurgen habermas bahwa penyelesaian sengketa ekonomi syari'ah melalui arbitrase ini lebih tepat karena dalam arbitrase itu memuat empat klaim tentang kebenaran, pertama adanya kesepakatan tentang dunia

\footnotetext{
30 Direktorat Jenderal Peradilan Agama, "Membedah Perma Tata Cara Penyelesaian Perkara Ekonomi Syariah",https://badilag.mahkamahagung.go.id/seputar-ditjen-badilag/seputarditjen-badilag/membedahperma-tata-cara-penyelesaian-perkara-ekonomi-syariah (diakses 12 Mei 2019).
} 
Osman

Kudrat Abdillah

alamiah dan objektif, yang berarti mencapai klaim kebenaran (truth), kedua adanya kesepakatan tentang pelaksanaan normanorma dalam dunia sosial, yang berarti mencapai klaim ketepatan (rightness), ketiga adanya kesepakatan tentang kesesuaian antara dunia batiniah dan ekspresi seseorang, yang berarti mencapai klaim autentisitas atau kejujuran" (sincerety), Dan yang keempat tercapainya kesepakatan atas klaim-klaim di atas secara keseluruhan, berarti mencapai klaim komprehensibilitas ${ }^{\text {ec }}$ (comprehensibility) ${ }^{31}$. Sedangakan penyelesaian sengketa ekonomi syari'ah dengan legitasi (peradilan) hanya memuat satu klaim kebenaran yaitu adanya kesepakatan tentang dunia alamiah dan objektif, yang berarti mencapai klaim kebenaran (truth).

\section{Daftar Pustaka}

Al-Qadla', Yahya Abdurrahman, dalam http:/ / hizbuttahrir.or.id/ main.php?page=alwaie\&id $=6$ 7\&print=1, diakses tanggal 15 Mei 2019

Asy-Syarwani, Hawâsyi asy-Syarwânî, X/101, Dar al-Fikr, Beirut. tt.

Abd al-Hayyi al-Kattani, at-Tarâtîb al-Idâriyah, I/258, Dar alKitab al-'Arabi, Beirut

Abdurrahman al-Baghdadi, Ulama dan Penguasa Dimasa Kejayaan dan Kemunduran, Jakarta: GIP, 1994

A. Mukti Arto, Garis Batas Kekuasaan Peradilan Agama dan Pengadilan Negeri, Penerapan Asas Personalitas KeIslaman sebagai Dasar Penentuan Kekuasaan Peradilan Agama, dalam Varia Peradilan No. 253 Desember 2006.

Rahmat Rosyadi dan Ngatino, Arbitrase dalam Perspektif Islam dan Hukum Positif, Bandung: PT. Citra Aditya Bhakti, 2002

Departemen Agama RI, al-Qur'an dan Terjemahannya.

Direktorat Jenderal Peradilan Agama, "Membedah Perma Tata Cara Penyelesaian Perkara Ekonomi

${ }^{31}$ Gerben Heitink, Practical Theology: History, Theory,Action Domains, Michigan, William B. Eerdmans Publishing Company, hal.. 135. 
Syariah",https://badilag.mahkamahagung.go.id/seputa r-ditjen-badilag/seputar-ditjenbadilag/membedahperma-tata-cara-penyelesaianperkara-ekonomi-syariah (diakses 12 Mei 2019).

Ensiklopedi Hukum Islam, Jilid V, Jakarta: PT.Ichtiar Baru Van Hoeve, 1997

Fathurrahman Djamil, Arbitrase Dalam Perspektif Sejarah Islam, dalam Arbitrase Islam di Indonesia, Badan Arbitrase Muamalat Indonesia Kerjasama dengan Bank Muamalat, Jakarta: BAMUI, 1994

Fatchur Rahman, Hadits-Hadits tentang Peradilan Agama Jakarta: Bulan Bintang, 1977

Gerben Heitink, Practical Theology: History, Theory,Action Domains, Michigan, William B. Eerdmans Publishing Company.

Imam al-Mawardi, Al-Ahkâm as-Sulthâniyyah wa al-wilâyah adDiniyyah (Hukum Tata Negara dan Kepemimpinan dalam Takaran Islam), penerjemah, Abdul Hayyi al-Kattani dan Kamaluddin Nurdin, Jakarta: GIP, 2000

Muhammad Khathib asy-Syarbini, Mughn al-Muhtâj, iv, Dar alFikr, Beirut

Muhammad bin Ismâ'îl Abû 'Abdillâh al-Bukhârî,Shahîh alBukhârî, Cet. 3, juz II (Beirût: Dâr Ibn Katsîr, 1987

Rifyal Ka'bah, Politik dan Hukum dalam al-Qur'an, Jakarta: Khairul Bayan, 2005

Satria Effendi M.Zein, Arbitrase Dalam Syariat Islam, dalam Arbitrase Islam di Indonesia, Badan Arbitrase Muamalat Indonesia Kerjasama dengan Bank Muamalat, Jakarta : BAMUI, 1994

Sutan Remy Sjahdeini, Penyelesaian Sengketa Transaksi Perbankan Syariah Melalui Arbitrase, disampaikan dalam Seminar Satu Dasawarsa Badan Arbitrase Syariah Nasional, Jakarta, 28 Januari 2004 